\title{
Artistic Endorsers are Catalysts for Airlines to Attract Passengers
}

\author{
Edward C. S. Ku \\ National Kaohsiung University of Hospitality and Tourism, Kaohsiung city, Taiwan (R.O.C)
}

Received: 30 May 2021. Revision received: 26 August 2021. Accepted: 11 October 2021

\begin{abstract}
The purpose of the study is to use the advertisements of four real airline artistic endorsers to analyze the contribution of the artistic endorser to discuss possible marketing strategies through an empirical questionnaire survey approach. Data were collected from the airport. Among them, 411 valid questionnaires were finally recovered. The hypothesis of the research model was tested by the SEM approach. The artistic endorser of the airline plays the role of catalyst in the marketing process to improve the airline's operational performance; this leads to our finding that the celebrity artistic endorsement should be carefully chosen in the airlines so that the image in advertising strategies and passengers' believing in celebrity endorsement would be matched; Airline companies are searching for strategies to develop stable connecting relationships with their passengers and to increase their company revenue by strengthening marketing strategy to deliver messages by utilizing the celebrity endorsement concept of passenger preferred airline based on their trust in celebrity endorser. This study contributes celebrity endorsement to the predictability of recommendation of airlines following artistic endorser sense-making of passengers' paradigm. As expected, the recommendation of airlines is most dominantly influenced by celebrity endorsement. Through empirical research, we supplement the significance of the artistic endorser sense-making perspective.
\end{abstract}

Key Words: celebrity endorsement, marketing capabilities, trustworthiness, recommendation.

\section{JEL Classification: M37}

Reference: Ku, E.C.S. (2021). Artistic Endorsers are Catalysts for Airlines to Attract Passengers. Journal of Tourism and Services, 23(12), 44-60. doi: 10.29036/jots.v12i23.269

\section{Introduction}

Advertisement is a famous communicative bridge between companies and consumers. To find a suitable artistic endorser for their product endorsement and strengthen consumers' impression of advertisement, companies would try their best to achieve these goals. From the perspective of consumers, endorsers have facilitated the efficiency of marketing commodities (Glaser, Krizek, \& King, 2020; Xu, Scott, \& Gao, 2017; Wang \& Scheinbaum, 2018). The purpose of companies is to win consumers' recognition of goods, which would motivate them to buy products that they expect.

The purpose of the study is to use the advertisements of four real airline artistic endorsers as shown in Figure 1, to analyze the contribution of the artistic endorser to discuss possible marketing strategies. Previous studies indicated that source-credibility leads to two factors, namely, expertness and trustworthiness (Vinzenz, 2019). However, according to airline product characteristics, mere trustworthiness and enjoyment were discussed in our research model, and expertness was excluded because our selected celebrity endorser is not the only expert in the airline industry, but we argued that airlines endorsement still generates a significant impact on passengers' recommendation behaviours. This 


\section{JOURNAL OF TOURISM AND SERVICES}

Issue 23, volume 12, ISSN 1804-5650 (Online)

www.jots.cz

also leads to our primary purpose of analysing the relevance between celebrity endorsements towards purchase intention.

Figure 1. Airlines' Advertising of Artist endorser in the research

\begin{tabular}{|c|c|c|c|}
\hline China Airline & Emirates & EVAAIR (I) Hello Kitty & EVA AIR (II) I See You \\
\hline & Emirates & \\
\hline
\end{tabular}

Source: the authors' own contribution

According to studies in the past, it was often discussed that advertising endorser must show reliable characteristics (Faroqi, Mesbah, \& Kim, 2019; Ferguson \& Mohan, 2020), which means that advertising endorser could reflect the characteristics of products in consumers hearts and expectations toward products (Bilotkach \& Pai, 2020; Seetanah, Sannassee, Teeroovengadum, \& Nunkoo, 2019; Vatankhah, Zarra-Nezhad, \& Amirnejad, 2019). According to the previous study, celebrity endorsement of airline advertisements would likely increase passengers' attentiveness, make the advertisement credible and persuasive (Dray, Doyme, \& Schafer, 2020; Faheem Gul Gilal, Justin Paul, Naeem Gul Gilal, \& Rukhsana Gul Gilal, 2020; Vatankhah, Zarra-Nezhad, \& Amirnejad, 2019), and add glamour as well as profit to the airline company.

On the other hand, the trust brought by the advertising endorser could enhance the brand value of the company (Raza, Iftikhar, Mohamad, Pembecioglu, \& Altaf, 2020; Yu \& Hu, 2020); moreover, many researchers were exploring how to develop marketing or advertising strategies with the help of the advertising endorser to gain an advantage in a competitive market while enhancing brand effectiveness (Zakari, Dogbe, \& Asante, 2019). However, because of the unique marketing characteristics owned by the aviation industry, the endorsers could not be the primary role of the product (Leon \& Martín, 2020; Punel, Hassan, \& Ermagun, 2019; So, King, Hudson, \& Meng, 2017; Princes, Manurung, So, \& Abdinagoro, 2020). From the perspective of sense-making, there are some reasons for passengers to choose airlines when there are some factors, such as routes, airlines' prestige, ticket prices, and services are taken into consideration. For airlines, the load factor and business performance would be improved if passengers become more motivated to take a flight after being stimulated by the above factors. Therefore, airlines would attract passengers in different travel markets through various marketing strategies, such as price strategies, member mileage accumulation, etc., which are conventional marketing strategies.

In addition, many researchers have discussed that companies would apply the role of advertising endorser, influencing consumers' tendency to repurchase products (Zhu, Amelina, \& Yen, 2020). Also, it was argued that consumers' buying intentions are often driven by effective advertising in previous research. Therefore, consumers' attitudes towards advertising and their purchasing intentions would be influenced by the endorser's credibility (Tran, Yazdanparas, \& Strutton, 2019). Furthermore, it was shown that with the endorsements of the celebrity, more positive and higher responses from purchasing would be made to consumers after the advertising is executed, compared to non-celebrity endorsement advertising scenarios, according to the previous research, all these results prove that persuasive endorsement would be feasible (Gilal, Paul, Gilal, \& Gilal, 2020). That is the reason why celebrity endorsement has become an important component of modern marketing.

From the passenger's perspective, airline celebrities have their own value that makes passengers trust the celebrity (Ha, Muthaly, \& Akamavi, 2010; Jung, Han, \& Oh, 2017; Mehta et al., 2020). Passengers 


\section{JOURNAL OF TOURISM AND SERVICES}

Issue 23, volume 12, ISSN 1804-5650 (Online)

www.jots.cz

believe that the product endorsed by the celebrity has good quality; they also believe that the celebrity had used the product they are endorsing. Besides, the source of attractiveness by the celebrity also plays an important role. A study showed that the physical attractiveness of a celebrity generates a positive impression on the product and a greater intention of purchasing. (Chiambaretto \& Fernandez, 2016). Simultaneously, from the perspective of the airline industry, the successful advertisement brings a pleasurable and enjoyable feeling to passengers. If the passenger's experience aligns with the celebrity's message of endorsement, the celebrity's trustworthiness would be convinced and increased (Vatankhah et al., 2019). According to some findings in other studies, it was discussed that the trustworthiness of celebrity in advisement has significant impacts on consumer's behavior of buying (Schouten, Janssen, \& Verspaget, 2020; Trivedi, 2018a). Thereby, it will affect the passenger's intention to purchase in the future. On the other hand, trustworthiness is one of the sources of credibility which has been used in many types of research. According to one of the previous studies, it was discussed that the persuasibility of communication impact would be more effective when the celebrity is found highly trustworthy.

It was explained how celebrity endorsement in airlines affects passengers' behavior in this study. Data were obtained by randomly invited passengers from international airports. LISREL software (Structural equation modelling approach; SEM approach) was applied to examine the research model in the proposal. The finding of the research states artistic endorser of the airline plays the role of catalyst in the marketing process to improve the airline's operational performance.

\section{Literature review}

\subsection{Artistic endorser sense-making of passengers}

Sense-making is a process of how people pay attention to the clues in the environment and create meanings between subjects through the cycle of interpretation and action. It involves cognition and understanding to formulate logical thinking of their own (Carrillat \& Ilicic, 2019; Ilicic, Kulczynski, \& Baxter, 2018). When advertisers use specific images or characters to attract consumers' attention and persuade them to buy products, the artistic endorser's perception of advertising will occur ( $\mathrm{Seo}, \mathrm{Li}$, Choi, \& Yoon, 2018; Yu, Zhang, Lin, \& Wu, 2020). Therefore, through the informative characteristics of the artistic endorser, the passengers' inquiries about the image and projection would suit themselves and the artistic endorser; such an interactive process would shape the overall image of the airline.

In previous studies, it was argued that source-attractiveness had become an important factor through the increasing number of celebrities endorsing products and services (Jung et al., 2017). Moreover, this research involves source credibility and source attractiveness as celebrity attributes in their studies (Brown, Swani, \& Mudambi, 2020; Nastisin, Gavurova, Bacik, Svetozarovova, \& Fedorko, 2021; Trivedi, 2018b). In other words, celebrities would play an important factor in the advertisement.

Figure 2. Research model

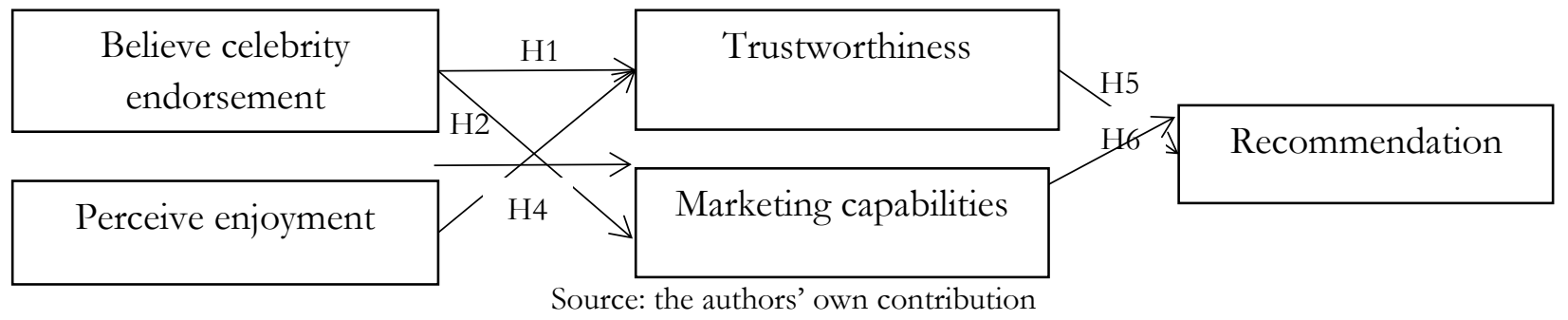

Following the perspective of the artistic endorser's sense-making of advertising, we will examine two keys that indicate variables that are related to the recommendation of purchasing of products directly, 


\section{JOURNAL OF TOURISM AND SERVICES}

Issue 23, volume 12, ISSN 1804-5650 (Online)

www.jots.cz

namely, celebrity endorsement and perceptive enjoyment of airlines. Figure 2 draws the relationships between the critical constructs analyzed among the research model.

\subsection{Believe celebrity endorsement}

Celebrity endorsement refers to celebrities who have been recognized and appreciated among the masses and represent consumers' products through the appearance in advertisements to make consumers think of products (Carrillat \& Ilicic, 2019; Schouten et al., 2020). Celebrities often play endorsers to make the advertisements more believable (Pickett \& Brison, 2019) and make the communication of the advertisement more effective. According to past studies, it was pointed out that when the image of celebrity endorsers matches their ideal model, which makes passengers find the suitability between the celebrities and promotional products or services, this promotional strategy would be more convincing. In other words, artistic personalities could help increase awareness of the corporate brand, generate a positive brand attitude to consumers, and develop brand loyalty.

Endorsers are assigned to display and sell products by enterprises whose purpose is to attract consumers' eyes and make consumers think they are truly endorsers in advertising (Hussain, Melewar, Priporas, Foroudi, \& Dennis, 2020; Punel et al., 2019; Qiu \& Haugland, 2019). Celebrity endorsement addresses the passengers' needs from the angle of psychology. According to the studies, it was shown that celebrities assigned by airlines get engaged in advertising to make passengers distinguish different characteristics of products and create subjective images. Celebrity endorsement advertising strategies have been displayed to effectively affect passengers' perception of product differences. Consequently, it will affect passengers' decisions toward promoted products. For airlines, artistic endorsers play a central role in attracting passengers' attention to endorsers themselves and their advertisements. Celebrity-based advertising conveys its content and purpose to cause the appeal of brands to passengers in the enterprise.

\subsection{Trustworthiness toward celebrity}

Trustworthiness in celebrities refers to the extent of how consumers think of celebrities. Artistic endorsers could convey sincere, cute, and trustworthy feelings to consumers by advertising products through media (Breves, Liebers, Abt, \& Kunze, 2019; Civelek, Kljucnikov, Krajcik, \& Zufan, 2019; PenaMarin \& Wu, 2019; Trivedi, 2018b; Vinzenz, 2019). The symbolic and ideal interests displayed by artistic endorsers in advertising will effectively develop the tactic of how companies maintain the consumers' self-identity (Halldórsson \& Wehner, 2020; Suk, Kim, \& Kim, 2020). Therefore, passengers may maintain long-term trading activities with airlines recognized by celebrities. The image of artistic endorsers could enable airlines to continue gaining advantages from passengers' self-definition.

Consumers increase their trust in products through their faith in the product spokespersons in advertisements (Ilicic et al., 2018; Lord, Putrevu, \& Collins, 2019) In; this way, airlines could increase the sale volume of products that were endorsed. The credibility of the airline's artistic endorsers would enhance the dignity of passengers' expectations, the credibility of airlines, and the attributes of trusted airlines. When passengers consider artistic celebrities to be trustworthy, they will consider the message conveyed by airlines to be highly credible. Passengers' emotional credibility with spokespersons is more important than attraction. Once passengers believe that the recognized artistic endorsers are trustworthy and respected, their recognition of the airline brand would become more positive.

Research has argued that the trustworthiness of artistic celebrities is a way to make passengers more confident in selecting airlines (Schouten et al., 2020). Likewise, it was also stated that naked celebrities could make passengers' focus on the quality of airlines, and the brand reliability would be improved through artistic endorsers in previous studies. Finally, they are more motivated to buy the products. Therefore, the credibility of artistic celebrities in advertising has a significant effect on competition in the 


\section{JOURNAL OF TOURISM AND SERVICES}

Issue 23, volume 12, ISSN 1804-5650 (Online)

www.jots.cz

aviation industry because it also affects passengers' intentions to purchase air tickets through the honest and upright image of artistic celebrities. Also, from the perspective of the aviation industry, many potential passengers have never taken a flight. Still, they likely have seen the artistic celebrities in the advertisements and booked journey tickets based on the credibility of the celebrities. Thus, this leads to Hypothesis 1.

H1: Believing celebrity endorsement of advertising is positively associated with trustworthiness toward celebrity for passengers.

\subsection{Marketing capabilities of airlines}

The airline's marketing capabilities are defined as the process of how airlines integrate strategies of sales. This process would alter the airline's core resources, knowledge of exploring consumer needs, and demonstrating outstanding market performance (Buhalis et al., 2019; Lawson, Tomchik, Muro, \& Krans, 2019; Lemken \& Rowe, 2020). Marketing capabilities are a powerful core competence of a company. It could not only directly contribute to the company performance by understanding key consumption, channels, and market alliances but also bring greater market share to the company (Cobena, Gallego, \& Casanueva, 2019; Tang, Wu, \& Tan, 2020). According to previous studies, it was also argued that marketing capabilities could exhibit what the company shared with the market in major products, the promotion of new products into the market, the capability of product after-sales service, and the capabilities of advertising sales. In other words, from the perspective of airlines, commodity endorsers are viewed as part of marketing capabilities, which could compensate for the market competitiveness of air tickets on the same voyage of the airline market.

Marketing capabilities have been considered as the key factor that determines the excellent performance of the company and could effectively respond to the dynamic needs of consumers in complex markets. When a company integrates its available unique resources with employees' personal knowledge and skills, it will develop its unique marketing capabilities. According to previous studies, it was found that the marketing capabilities displayed in airline advertisements would make passengers pay more attention to airline advertisements and purchase more products. Passengers generally think that artistic endorsers are more attractive in drawing people's attention to the brand than non-celebrities are. Simultaneously, passengers are more likely to form positive celebrity endorsements, making artistic endorsers generate higher purchase intentions than their unappealing rivals.

In the airline industry, marketing capabilities play an important role in attracting the passenger's attention. Therefore, a successful relationship between celebrities and airline companies is one of the most effective ways for airline companies to extend their marketing efforts. In addition, marketing capabilities would be boosted when airline companies interested in increasing sales volume would market their product well if the celebrity has higher attractiveness as an artistic endorser. Airline companies often highlight celebrity endorsement as a new marketing instrument for increasing corporate reputation for passengers and achieving their marketing capabilities further. This leads to our hypothesis 2 :

H2: Believing celebrity endorsement of advertising is positively associated with the marketing capabilities of airlines. 


\section{JOURNAL OF TOURISM AND SERVICES}

Issue 23, volume 12, ISSN 1804-5650 (Online)

www.jots.cz

\subsection{Perceived enjoyment of taking airlines}

The feeling of enjoyment presents a form of intrinsic motivation where individuals engage in a specific deed that provides fun and entertainment (Ku, 2020; Li, Xu, \& Chen, 2020). Besides, enjoying the flight could be regarded as the process of providing fun and joy during the passengers' journey in the airline. Therefore, during the activity, the more enjoyment consumers feel, the more activities they are willing to undertake (Sevilla, Lu, \& Kahn, 2019; van Pinxteren, Wetzels, Ruger, Pluymaekers, \& Wetzels, 2019; Weinberger \& Gulas, 2019). Thus, perceived enjoyment is an affective variable that is considered important towards this deed.

The feeling of enjoyment has the largest impact on passenger's intention and behavior. According to previous studies, it was found that passengers' behavior would be improved under the recommendation of others when they received enjoyment with a higher level from their prior experience (Roucolle, Seregina, \& Urdanoz, 2020; Tang, Liu, Liu, \& Ma, 2019). Furthermore, the result has manifested those consumers will merely purchase the products if they find them enjoyable. Therefore, enjoyment brought from celebrity endorsement could be theorized as it generates a direct influence on passengers' attitude and purchase intention.

From the perspective of airline companies, passengers who took the flight would own enjoyable, pleasurable, fun, exciting, or interesting experiences that would consider the next arrangement of purchase. In addition, the enjoyment felt by the passengers would also affect how trustworthy the celebrity would be since the celebrity endorsement in the advertisement projects is an enjoyable, pleasurable, fun, exciting, and interesting experience of service in airlines. Thus, it is expected that passengers would have the same experience of aligning with the endorser's message. This leads to hypothesis 3:

H3: Perceived enjoyment is positively associated with trustworthiness toward celebrity.

Airline companies that adapt endorsement advertisements to build attractive communicators consistently have an impact on the products and services of flights that the communicators endorse. Furthermore, in combination with experiences of flying, passengers would engage in more enjoyable, pleasurable, exciting, and interesting feelings through endorsement advertisements of airline companies. Based on the above discussion, it leads to hypothesized 4.

H4: Perceived enjoyment is positively associated with the marketing capabilities of airlines.

\subsection{Recommendation of airlines}

Recommendations could be viewed as the consumer's intentions for product preferences and possible purchases and could also be viewed as a tendency to promote loyalty (Ohiomah, Benyoucef, \& Andreev, 2020). In other words, recommendation means consumers' will to adopt a given behavior as the key factor predicting whether they would do it. When a consumer chooses a product, the final decision to accept the product depends on suggestions from other consumers. Moreover, many external factors have been recognized, which could affect consumers' intentions to purchase the product. Passengers would recommend it to their friends because their own experience with airlines is wonderful. What the experience of airlines provided to passengers has become an essential factor in gaining a potential market.

According to previous studies, it has been argued how the credibility of the endorser impacts consumers' attitudes to the trust of advertisement. For airlines, passengers' responses and 


\section{JOURNAL OF TOURISM AND SERVICES}

Issue 23, volume 12, ISSN 1804-5650 (Online)

www.jots.cz

recommendations are critical to sales growth in the future, forming an important factor that attracts potential passengers (Ojo, 2019; Wen \& White; Kelic, Erceg, \& Candrlic-Dankos, 2020; Lucini, Tonetto, Fogliatto, \& Anzanello, 2020; Mira, Moura, \& Monico, 2018). Also, ticketing strategy and service innovation would improve the relationship between consumers and airlines.

Endorser's trustworthiness and expertise are qualifications that directly affects the degree of persuading passengers to take the flight. Thus, choosing a celebrity that has trustworthiness would increase the passengers' intention of purchase. Therefore, more loyal passengers would be found. Airline companies keep noticing the passengers' preference in the airline advertisement and make them proud of their choice. Furthermore, passengers would believe that trustworthiness is one trait an expert musthave. Besides, firm persuasion is also one of the marketing capabilities of airline products and services. In this research, the trustworthiness of a celebrity has a direct impact on the behavior of recommendation. This leads to the hypothesis as follows.

H5: Trustworthiness towards celebrities is positively associated with the recommendation of purchasing airline products.

Airlines' marketing capabilities are affected by organizational resources, a dynamic competitive environment, and passenger demand (Kohl, Gross, Henning, \& Baumgarten, 2020; Loo, 2020). In other words, the marketing of airlines is a kind of ability to improve the perception of the tourism market and respond to the dynamic competitive market. Airlines provide passengers with a higher level of value to meet their personal needs, which indicates that marketing capabilities through active and aggressive ways would impact the ways how passengers behave or think about the brands in the airline. Internally, concerning the strategies of airlines and endorsement of advertising, the leadership could also significantly increase intentions under recommendations by passengers' purchasing based on their experience of flight in the airline. Thus, the final hypothesis is conducted based on the above discussion.

H6: Marketing capabilities of airlines is positively associated with the recommendation of purchasing airline product.

\section{Methods}

First, we select four advertisements with endorsement advertisements (please see Appendix 1) it included EVA airline, China airline, and Emirate's airline (EVA airline launched two endorsement advertisements).

Three Tourism management professors were invited to verify survey items and refined for translation accuracy. The Chinese questionnaire was then pre-tested with 30 passengers at Taoyuan Airport randomly; besides, passengers believe that the trustworthiness is like an expert, and it must have firm persuasion and, at the same time, be able to demonstrate the more substantial marketing capabilities of airline products and services.

Second, a paper survey was administered for data collection, and a stratified sampling process is used before the spread of COVID 19 in this study; we invite participants at the check-in counter of airlines; According to the queuing order, there are ten passengers in each compartment. We encourage one passenger to participate in the questionnaire; If the passenger refuses to answer, we record it as an invalid questionnaire; besides, the interviewees are not limited to flight destinations; however, the survey filled out after reading the advertisement of the flight is regarded as a valid questionnaire.

Third, for each advertising flight, we choose 300 passengers to answer (a total of 1200 passengers). After deducting the refusal and those who have not seen the trip, 411 valid questionnaires are recovered. Table 1 describes the characteristics of the sample. 
Table 1. Sample Description

\begin{tabular}{|l|c|c|}
\hline Item & Number & Percentage (\%) \\
\hline Gender & 153 & 37 \\
\hline Male & 261 & 63 \\
\hline Female & & \\
\hline Age & 43 & 10.4 \\
\hline$<20$ and 20 & 211 & 51.0 \\
\hline $21-30$ & 100 & 24.2 \\
\hline $31-40$ & 33 & 8.0 \\
\hline $41-50$ & 27 & 6.6 \\
\hline$>50$ & & \\
\hline Educational Qualifications & 3 & 0.7 \\
\hline Middle School & 38 & 9.2 \\
\hline High School & 308 & 74.4 \\
\hline Undergraduate & 65 & 15.7 \\
\hline Master and above & & \\
\hline Monthly Income (NT $\$)$ & 90 & 21.7 \\
\hline No income & 45 & 10.9 \\
\hline 20,000 and below & 124 & 30.0 \\
\hline $20,001-40,000$ & 77 & 18.6 \\
\hline $40,001-60,000$ & 35 & 8.5 \\
\hline $60,001-80,000$ & 43 & 10.4 \\
\hline 80,000 and above & & \\
\hline
\end{tabular}

Source: the authors' own contribution

The measures items in the survey were adapted from the significantly related studies conducted in the prior research, as indicated in Table 2, identified 21 research items; The different opinions are indicated from $1=$ strongly disagree to $5=$ strongly agree, following the Likert scale.

\section{Table 2. Sample Description}

\begin{tabular}{|l|l|c|}
\hline Factors & \multicolumn{1}{|c|}{ Item } & References \\
\hline Believes Celebrity & Endorsements (BCE) & Trivedi (2018a) \\
\hline BCE1 & Easily influenced by a celebrity endorser when I am choosing an airline & \\
\hline BCE2 & $\begin{array}{l}\text { Ever considered switching to another airline just because of the presence of a } \\
\text { celebrity I liked }\end{array}$ & \\
\hline BCE3 & Believe products specifically advertised by the celebrities have a good quality & \\
\hline BCE4 & Believe the celebrities also choose those airlines that they endorse & Ku (2020) \\
\hline Perceived Enjoyment (PE) & \\
\hline PE1 & Taking this airline is enjoyable & \\
\hline PE2 & Taking this airline is fun & Trivedi (2018b) \\
\hline PE3 & Taking this airline is exciting & \\
\hline PE4 & Taking this airline is interesting & \\
\hline Trustworthiness $($ TW $)$ & The celebrity endorser is honest & \\
\hline TW1 & The celebrity endorser is reliable & \\
\hline TW2 &
\end{tabular}




\begin{tabular}{|l|l|l|}
\hline TW3 & The celebrity endorser is trustworthy & \\
\hline TW4 & The celebrity endorser is dependable & \\
\hline TW5 & The celebrity endorser is sincere & Ha et al., (2010) \\
\hline Marketing capabilities (MC) & \\
\hline MC1 & This airline offers high quality products & \\
\hline MC2 & This airline sets reasonable price on the products & \\
\hline MC3 & This airline has wide sales networks & Chang (2015) \\
\hline MC4 & This airline invests a lot on research and development & \\
\hline MC5 & This airline well performs 'warrantee' policies to customers & \\
\hline Recommendation $($ REC) & \\
\hline REC1 & I will recommend this airline to my friends and relatives & \\
\hline REC2 & I will say positive things about this airline to others & \\
\hline REC3 & I will encourage others to choose this airline & \\
\hline
\end{tabular}

Source: the authors' own contribution

\section{Results}

Cronbach's coefficient has assessed the reliability of the survey items. Table 3 summarizes the reliability of statistics results; Cronbach's ratio of overall survey items was 0.95 , which is above the acceptable threshold.

Likewise, the discriminant validity and convergent validity of the survey items were statistics by confirmatory factor analysis (Dobrzykowski \& McFadden) following the SEM approach (with LISREL). Construct validity is based on theoretical hypotheses and the testing of theoretical predictions. In the testing process, we must first proceed from a constructed theory and draw up various underlying assumptions about the research model. As the results of statistics, factor loadings statistics range was from 0.63 to 0.95 in the study. Table 4 summarizes the statistics of CFA.

Table 3. Reliability

\begin{tabular}{|l|l|l|c|}
\hline Item & Mean & SD & Cronbach's $\alpha$ \\
\hline BCE1 & 3.02 & 1.014 & .922 \\
\hline BCE2 & 2.82 & .994 & .924 \\
\hline BCE3 & 2.86 & .897 & .922 \\
\hline BCE4 & 3.21 & .973 & .920 \\
\hline PE1 & 3.94 & .699 & .919 \\
\hline PE2 & 3.93 & .696 & .918 \\
\hline PE3 & 3.52 & .816 & .923 \\
\hline PE4 & 3.13 & .838 & .918 \\
\hline TW1 & 3.56 & .805 & .918 \\
\hline TW2 & 3.58 & .815 & .917 \\
\hline TW3 & 3.60 & .799 & .918 \\
\hline TW4 & 3.59 & .785 & .918 \\
\hline TW5 & 3.62 & .823 & .919 \\
\hline MC1 & 3.95 & .751 & .922 \\
\hline MC2 & 3.70 & .739 & .921 \\
\hline MC3 & 3.91 & .749 & \\
\hline
\end{tabular}




\begin{tabular}{|l|l|l|l|}
\hline MC4 & 3.71 & .760 & .920 \\
\hline MC5 & 3.81 & .754 & .920 \\
\hline MC6 & 4.01 & .759 & .919 \\
\hline REC1 & 3.71 & .797 & .919 \\
\hline REC2 & 3.76 & .764 & .920 \\
\hline REC3 & 3.69 & .798 & .920 \\
\hline
\end{tabular}

Note: $\mathrm{BCE}=$ Believes Celebrity Endorsements; PE $=$ Perceived Enjoyment; TW $=$ Trustworthiness; MC = Marketing capabilities; REC $=$ Recommendation

Source: the authors' own contribution

Table 4. Confirmatory Factor Analysis

\begin{tabular}{|c|c|c|c|c|c|}
\hline Construct Variables & $\mathrm{BCE}$ & PE & TW & $\mathrm{MC}$ & REC \\
\hline BCE1 & 0.74 & & & & \\
\hline BCE2 & 0.66 & & & & \\
\hline BCE3 & 0.75 & & & & \\
\hline BCE4 & 0.66 & & & & \\
\hline PE1 & & 0.64 & & & \\
\hline PE2 & & 0.66 & & & \\
\hline PE3 & & 0.86 & & & \\
\hline PE4 & & 0.82 & & & \\
\hline TW1 & & & 0.87 & & \\
\hline TW2 & & & 0.94 & & \\
\hline TW3 & & & 0.95 & & \\
\hline TW4 & & & 0.95 & & \\
\hline TW5 & & & 0.88 & & \\
\hline MC1 & & & & 0.77 & \\
\hline MC2 & & & & 0.57 & \\
\hline MC3 & & & & 0.60 & \\
\hline MC4 & & & & 0.70 & \\
\hline MC5 & & & & 0.69 & \\
\hline MC6 & & & & 0.80 & \\
\hline REC1 & & & & & 0.92 \\
\hline REC2 & & & & & 0.85 \\
\hline REC3 & & & & & 0.92 \\
\hline
\end{tabular}

Note: $\mathrm{BCE}=$ Believes Celebrity Endorsements; PE $=$ Perceived Enjoyment; TW $=$ Trustworthiness; MC = Marketing capabilities; REC $=$ Recommendation

Average variation extraction (AVE) to analyze the convergent validity of latent variables; AVE estimate will be higher than 0.50 , which indicates to confirm validity for all construct's measure (Ingvardson \& Nielsen, 2019). As shown in Table 5, all AVE statistics are indicating and assuring that all latent constructs have convergent validity. Moreover, to evaluate the efficacy of the discrimination between the constructs, the square root of the AVE calculated for each latent construct must be higher than the correlation coefficient between the latent constructs with others. The results state that the square root of all AVE estimates, which indicate the discriminant validity, is supported.

Table 5. Measurement model estimation 


\begin{tabular}{|l|c|c|c|c|c|c|c|c|}
\hline Item & Mean & $\begin{array}{c}\text { Standard } \\
\text { deviation }\end{array}$ & BEC & PE & TW & MC & REC & AVE \\
\hline BEC & 2.98 & .763 & $\mathbf{0 . 7 0}$ & & & & 0.49 \\
\hline PE & 3.61 & .613 & 0.467 & $\mathbf{0 . 7 4}$ & & & & 0.54 \\
\hline TW & 3.59 & .754 & 0.306 & 0.547 & $\mathbf{0 . 9 2}$ & & & 0.85 \\
\hline MC & 3.83 & .567 & 0.287 & 0.439 & 0.314 & $\mathbf{0 . 7 0}$ & 0.49 \\
\hline REC & 3.72 & .734 & 0.161 & 0.198 & 0.174 & 0.240 & $\mathbf{0 . 9 0}$ & 0.81 \\
\hline
\end{tabular}

Note:

BCE = Believes Celebrity Endorsements; PE = Perceived Enjoyment; TW = Trustworthiness; MC = Marketing capabilities; REC $=$ Recommendation

Square root of AVE for each construct was shown in the diagonal of the correlation matrix.

Source: the authors' own contribution

SEM approach (LISREL 8.50 software) for hypothesis testing of this research. The overall goodness-of-fit (GOF) was valued to identify degree of model fit, and the following fit indexes included (Bagiran \& Kurgun, 2016): AGFI=0.86; GFI=0.89; RMR=0.037; RMSEA=0.064; CFI= 0.95, NFI= $0.92 ; \mathrm{PNFI}=0.81$; and PGFI $=0.71$. the results show hypothesized structural model indicating a good degree of model fit in the study.

Table 6. Results of hypothesis testing

\begin{tabular}{|l|l|c|r|}
\hline \multicolumn{2}{|l|}{ Hypotheses } & t Value & Results \\
\hline H 1 & Believes Celebrity Endorsements $\rightarrow$ Trustworthiness & $6.97^{* *}$ & Supported \\
\hline H 2 & Believes Celebrity Endorsements $\rightarrow$ Marketing capabilities & $2.99^{*}$ & Supported \\
\hline H 3 & Perceived Enjoyment $\rightarrow$ Trustworthiness & $6.50^{* *}$ & Supported \\
\hline H 4 & Perceived Enjoyment $\rightarrow$ Marketing capabilities & $9.58^{* * *}$ & Supported \\
\hline H 5 & Trustworthiness $\rightarrow$ Recommendation & 1.40 & Not Supported \\
\hline H 6 & Marketing capabilities $\rightarrow$ Recommendation & $11.19^{* * *}$ & Supported \\
\hline
\end{tabular}

$* \mathrm{P}<0.05, * * \mathrm{P}<0.01, * * * \mathrm{P}<0.001$.

Source: the authors' own contribution

\section{Discussion}

The use of the SEM approach to testing the theoretical model of celebrity endorsement could lead to a more comprehension of endorsement in airlines' marketing and passengers' recommendation behaviours.

First, selecting a celebrity endorsement will be an essential aspect for the airline industry is doing its marketing strategy. The result of our research shows that believe celebrity endorsement is positively associated with trustworthiness toward the celebrity $\left(\mathrm{t}=6.97^{* *}, \mathrm{p}<0.01\right)$ and the marketing ability of airlines $(\mathrm{t}=2.99 *, \mathrm{p}<0.05)$; believe celebrity endorsement is an important factor affecting trustworthiness toward the celebrity of passenger and the marketing ability of airlines, which is consistent with Ilicic et al. (2018) and Lord et al. (2019). It indicates that passengers that believe in celebrity endorsement can make a substantial contribution to purchase intention through the transfer of celebrity endorsements.

Accordingly, airlines should carefully choose celebrity artistic endorsement that matches the image in advertising strategies; passengers' believing in celebrity endorsement has the least influence on passengers' purchase behaviours.

Second, Airlines should incorporate artistic endorsers into a moving image in advertising strategies to attract passengers' willingness to board. In our analysis, perceived enjoyment is positively associated with trustworthiness $\left(\mathrm{t}=6.50^{* *}, \mathrm{p}<0.01\right)$ and the marketing capabilities of airlines $\left(\mathrm{t}=9.58^{* * *}, \mathrm{p}<0.001\right)$. Companies must attach importance to consumers' brand experience to shape corporate brand 


\section{JOURNAL OF TOURISM AND SERVICES}

Issue 23, volume 12, ISSN 1804-5650 (Online)

www.jots.cz

satisfaction which is as same results as Buyukdag and Kitapci (2021). Therefore, we can conclude that it has an essential meaning for airline companies to preserve the enjoyment that the passenger received.

Airlines will provide customers with value-added customer relationship strategies for passengers; moreover, the airline offers high-quality products with reasonable prices on the product, to execute favorable marketing capabilities, and stand out in a competitive market. Additionally, Airlines can combine the characteristics of the artistic endorser to develop products around travel that have provided passengers with airline flights the pleasure of travel.

Third, the trustworthiness of the celebrity is an important and essential attribute in celebrity endorsement; a celebrity endorser is considered as an attractive person and who can influence passengers' purchase intention. Our study result shows trustworthiness is not positively associated with the recommendation of airlines ( $\mathrm{t}=1.40, \mathrm{p}>0.05)$; Compared with Krajcik, \& Zufan (2019) project, trustworthiness are nearly related to the recommendation of airlines; Thus, this represents that airline companies should be accorded to their target market, then cooperate with a celebrity with higher attractiveness and fame toward them to increase their trust toward both celebrity endorsers and companies in further boosting the purchase intention of passengers.

Airlines should carefully choose artistic endorsers to let passengers feel the authenticity of the artistic endorser in the advertisements and the airline's trust in passengers' hearts. A trustworthy celebrity can directly impact passengers' faith in the airline company. For instance, Takeshi Kaneshiro, the celebrity endorser of EVA Airline in Taiwan, relying on his trustworthy image, convinces other passengers that EVA airline is the best airline company. Besides, passengers will also purchase the product if the airline company is endorsed by a celebrity that the passenger liked. For example, a fan of Hello Kitty is likely to buy EVA airline's product instead of China Airlines in the circumstance of flying to the same destination.

Finally, our research showed that marketing ability is positively associated with the recommendation of airlines $\left(\mathrm{t}=11.99^{* * *}, \mathrm{p}<0.001\right)$. Which we can also say that the marketing ability of airline companies are more trustworthy than companies that have no celebrity's name attached to it; furthermore, passengers are often to believe that a product is endorsed by a celebrity is of good quality.

Combining artistic endorser $s$ to become an airline's marketing capability is a particularly important part. When an artistic endorser can make passengers feel the charm of airlines, they can increase their willingness to take airlines. The purchase intention of passengers is needed for airline companies to increase their revenue, which is also the highlight of the effects that celebrity endorsements bring. From our research, we can say that in the marketing field, choosing the right celebrity to endorse a product will increase passenger's purchase intention. That is, a stronger trust relationship between passengers and celebrity endorser is required for airlines. Therefore, the improvement of cautiousness in selecting celebrity endorsers for airline companies is essential to have a significant impact on their revenue.

\section{Conclusion}

This study contributes celebrity endorsement to the predictability of recommendation of airlines following artistic endorser sense-making of passengers' paradigm. Overall, the results provide interesting insights for the proposed model of the recommendation of airlines. As expected, the recommendation of airlines is most dominantly influenced by celebrity endorsement. Through empirical research, we supplement the significance of the artistic endorser sense-making perspective.

The significant contribution of this research lies in the artistic endorser sense-making of passengers' perspective. After empirical analysis, the artistic endorser of the airline plays the role of catalyst in the marketing process to improve the airline's operational performance. As airline companies' image is the first association of passengers' impression toward the company, especially in the airline industry, therefore, their marketing department must be more focused on the advertisement and celebrity endorsement they launch. Airline companies are searching for strategies to develop stable connecting 


\section{JOURNAL OF TOURISM AND SERVICES}

Issue 23, volume 12, ISSN 1804-5650 (Online)

www.jots.cz

relationships with their passengers and to increase their company revenue by strengthening marketing strategy to deliver messages by utilizing the celebrity endorsement concept of passenger preferred airline based on their trust in celebrity endorser. This study assumed that celebrity endorser plays an essential role in influencing passenger in making recommendation behaviours. Celebrities create belief and trust in themselves and then create interest in passengers to purchase the product.

\section{References}

1. Bagiran, D., \& Kurgun, H. (2016). A research on social impacts of the Foca Rock Festival: the validity of the Festival Social Impact Attitude Scale. Current Issues in Tourism, 19(9), 930-948. doi:10.1080/13683500.2013.800028

2. Bilotkach, V., \& Pai, V. (2020). A Price for Delays Price-quality Competition in the US Airline Industry. Journal of Transport Economics and Policy, 54, 151-176. Retrieved from <Go to ISI>://WOS:000572480500004

3. Breves, P. L., Liebers, N., Abt, M., \& Kunze, A. (2019). The Perceived Fit between Instagram Influencers and the Endorsed Brand How Influencer-Brand Fit Affects Source Credibility and Persuasive Effectiveness. Journal of Advertising Research, 59(4), 440-454. doi:10.2501/jar-2019-030

4. Brown, B. P., Swani, K., \& Mudambi, S. M. (2020). Introduction to the special issue: B2B advertising. Industrial Marketing Management, 89, 578-580. doi:10.1016/j.indmarman.2020.02.006

5. Buhalis, D., Harwood, T., Bogicevic, V., Viglia, G., Beldona, S., \& Hofacker, C. (2019). Technological disruptions in services: lessons from tourism and hospitality. Journal of Service Management, 30(4), 484-506. doi:10.1108/josm-12-2018-0398

6. Carrillat, F. A., \& Ilicic, J. (2019). The Celebrity Capital Life Cycle: A Framework for Future Research Directions on Celebrity Endorsement. Journal of Advertising, 48(1), 61-71. doi:10.1080/00913367.2019.1579689

7. Chang, K. C. (2015). How travel agency reputation creates recommendation behavior. Industrial Management \& Data Systems, 115(2), 332-352. doi:10.1108/imds-09-2014-0265

8. Chiambaretto, P., \& Fernandez, A. S. (2016). The evolution of coopetitive and collaborative alliances in an alliance portfolio: The Air France case. Industrial Marketing Management, 57, 75-85. doi:10.1016/j.indmarman.2016.05.005

9. Civelek, M., Kljucnikov, A., Krajcik, V., \& Zufan, J. (2019). The Importance of Discount Rate and Trustfulness of A Local Currency for the Development of Local Tourism. Journal of Tourism and Services, 10(19), 77-92. doi:10.29036/jots.v10i19.117

10. Cobena, M., Gallego, A., \& Casanueva, C. (2019). Diversity in airline alliance portfolio configuration. Journal of Air Transport Management, 75, 16-26. doi:10.1016/j.jairtraman.2018.11.004

11. Dobrzykowski, D. D., \& McFadden, K. L. (2020). Examining Governance in Hospital Operations: The Effects of Trust and Physician Employment in Achieving Efficiency and Patient Satisfaction. Decision Sciences, 51(1), 74-109. doi:10.1111/deci.12414

12. Dray, L., Doyme, K., \& Schafer, A. W. (2020). Airline Profit Maximisation, Cost Pass-through, and Scarcity Rents in Capacity-constrained Aviation Systems. Journal of Transport Economics and Policy, 54, 244-266. Retrieved from <Go to ISI>://WOS:000612681600002

13. Faroqi, H., Mesbah, M., \& Kim, J. (2019). Behavioural advertising in the public transit network. Research in Transportation Business \& Management, 32, 100421. doi:https://doi.org/10.1016/j.rtbm.2019.100421

14. Ferguson, J. L., \& Mohan, M. (2020). Use of celebrity and non-celebrity persons in B2B advertisements: Effects on attention, recall, and hedonic and utilitarian attitudes. Industrial Marketing Management, 89, 594-604. doi:10.1016/j.indmarman.2019.02.003 


\section{JOURNAL OF TOURISM AND SERVICES}

Issue 23, volume 12, ISSN 1804-5650 (Online)

www.jots.cz

15. Gilal, F. G., Paul, J., Gilal, N. G., \& Gilal, R. G. (2020). Celebrity endorsement and brand passion among air travelers: Theory and evidence. International Journal of Hospitality Management, 85, 102347. doi:https://doi.org/10.1016/j.ijhm.2019.102347

16. Gilal, F. G., Paul, J., Gilal, N. G., \& Gilal, R. G. (2020). Celebrity endorsement and brand passion among air travelers: Theory and evidence. International Journal of Hospitality Management, 85, 9. doi:10.1016/j.ijhm.2019.102347

17. Glaser, M., Krizek, K. J., \& King, D. A. (2020). VIEWPOINT: Accelerating reform to govern streets in support of human-scaled accessibility. Transportation Research Interdisciplinary Perspectives, 7, 100199. doi:https://doi.org/10.1016/j.trip.2020.100199

18. Ha, H. Y., Muthaly, S. K., \& Akamavi, R. K. (2010). Alternative explanations of online repurchasing behavioral intentions A comparison study of Korean and UK young customers. European Journal of Marketing, 44(6), 874-904. doi:10.1108/03090561011032757

19. Halldórsson, Á., \& Wehner, J. (2020). Last-mile logistics fulfilment: A framework for energy efficiency. Research in Transportation Business \& Management, 37, 100481. doi:https://doi.org/10.1016/j.rtbm.2020.100481

20. Hussain, S., Melewar, T. C., Priporas, C.-V., Foroudi, P., \& Dennis, C. (2020). Examining the effects of celebrity trust on advertising credibility, brand credibility and corporate credibility. Journal of Business Research, 109, 472-488. doi:https://doi.org/10.1016/j.jbusres.2019.11.079

21. Ilicic, J., Kulczynski, A., \& Baxter, S. M. (2018). How a Smile Can Make a Difference: Enhancing the Persuasive Appeal Of Celebrity Endorsers Boosting Consumer Perceptions of Celebrity Genuineness Through the Use of a "Duchenne Smile" in Advertising. Journal of Advertising Research, 58(1), 51-64. doi:10.2501/jar-2016-003

22. Ingvardson, J. B., \& Nielsen, O. A. (2019). The relationship between norms, satisfaction and public transport use: A comparison across six European cities using structural equation modelling. Transportation Research Part a-Policy and Practice, 126, 37-57. doi:10.1016/j.tra.2019.05.016

23. Jung, J., Han, H., \& Oh, M. (2017). Travelers' switching behavior in the airline industry from the perspective of the push-pull-mooring framework. Tourism Management, 59, 139-153. doi:10.1016/j.tourman.2016.07.018

24. Kelic, I., Erceg, A., \& Candrlic-Dankos, I. (2020). Increasing tourism competitiveness: Connecting Blue and Green Croatia. Journal of Tourism and Services, 11(20), 132-149. doi:10.29036/jots.v11i20.138

25. Kohl, J., Gross, A., Henning, M., \& Baumgarten, T. (2020). Driver glance behavior towards displayed images on in-vehicle information systems under real driving conditions. Transportation Research Part F-Traffic Psychology and Behaviour, 70, 163-174. doi:10.1016/j.trf.2020.01.017

26. Ku, E. C. S. (2020). Spreading distinctive insignia benefits from mobile service: evidence from a mobile application of transportation, Transportation Planning and Technology, 43(7), 651-669, DOI: 10.1080/03081060.2020.1805542

27. Lawson, C. T., Tomchik, P., Muro, A., \& Krans, E. (2019). Translation software: An alternative to transit data standards. Transportation Research Interdisciplinary Perspectives, 2, 100028. doi:https://doi.org/10.1016/j.trip.2019.100028

28. Lemken, R. K., \& Rowe, W. J. (2020). Unpacking the efficacy of organizational routines in the financial services industry. Journal of Services Marketing, 34(5), 735-747. doi:10.1108/jsm-05-20190205

29. Leon, S., \& Martín, J. C. (2020). A fuzzy segmentation analysis of airline passengers in the U.S. based on service satisfaction. Research in Transportation Business \& Management, 37, 100550. doi:https://doi.org/10.1016/j.rtbm.2020.100550

30. Li, M. M., Xu, W. Q., \& Chen, Y. H. (2020). Young children's vacation experience: Through the eyes of parents. Tourism Management Perspectives, 33, 9. doi:10.1016/j.tmp.2019.100586 


\section{JOURNAL OF TOURISM AND SERVICES}

Issue 23, volume 12, ISSN 1804-5650 (Online)

www.jots.cz

31. Loo, P. T. (2020). Exploring airline Companies' engagement with their passengers through social network: An investigation from their Facebook pages. Tourism Management Perspectives, 34, 9. doi:10.1016/j.tmp.2020.100657

32. Lord, K. R., Putrevu, S., \& Collins, A. F. (2019). Ethnic influences on attractiveness and trustworthiness perceptions of celebrity endorsers. International Journal of Advertising, 38(3), 489505. doi:10.1080/02650487.2018.1548196

33. Lucini, F. R., Tonetto, L. M., Fogliatto, F. S., \& Anzanello, M. J. (2020). Text mining approach to explore dimensions of airline customer satisfaction using online customer reviews. Journal of Air Transport Management, 83, 12. doi:10.1016/j.jairtraman.2019.101760

34. Mehta, R., Rice, S., Winter, S. R., Anania, E. C., Baugh, B. S., \& Milner, M. N. (2020). Determining the predictors for ease of sleep while on aircraft: Regression and qualitative analyses. Journal of Air Transport Management, 83, 8. doi:10.1016/j.jairtraman.2019.101756

35. Mira, M. D. C., Moura, A. F. A., \& Monico, L. D. (2018). A New Measure of the Quality of Tourism Product. Journal of Tourism and Services, 9(17). doi:10.29036/jots.v9i17.54

36. Nastisin, L., Gavurova, B., Bacik, R., Svetozarovova, N. \& Fedorko, R. (2021). Sustainable performance of players in the global aviation industry in the light of multi-factor analysis of online reputation. International Journal of Entrepreneurial Knowledge, 9(1), 1-9. doi: 10.37335/ijek.v9i1.130

37. Ohiomah, A., Benyoucef, M., \& Andreev, P. (2020). A multidimensional perspective of businessto-business sales success: A meta-analytic review. Industrial Marketing Management, 90, 435-452. doi:10.1016/j.indmarman.2020.08.011

38. Ojo, T. K. (2019). Quality of public transport service: an integrative review and research agenda. Transportation Letters-the International Journal of Transportation Research, 11(2), 104-117. doi:10.1080/19427867.2017.1283835

39. Pena-Marin, J., \& Wu, R. M. (2019). Disconfirming Expectations: Incorrect Imprecise (vs. Precise) Estimates Increase Source Trustworthiness and Consumer Loyalty. Journal of Consumer Psychology, 29(4), 623-641. doi:10.1002/jcpy.1117

40. Pickett, A. C., \& Brison, N. T. (2019). Lose like a man: body image and celebrity endorsement effects of weight loss product purchase intentions. International Journal of Advertising, 38(8), 10981115. doi:10.1080/02650487.2019.1586208

41. Princes, E., Manurung, A. H., So, I. G., \& Abdinagoro, S. B. (2020). A closer look at the Consumer Conformity in Industry 4.0 : Purchase Intention redefined. Polish Journal of Management Studies, 22(1), 401-417. DOI 10.17512/pjims.2020.22.1.26

42. Punel, A., Hassan, L. A., \& Ermagun, A. (2019). Variations in airline passenger expectation of service quality across the globe. Tourism Management, 75, 491-508. doi:10.1016/j.tourman.2019.06.004

43. Qiu, X. L., \& Haugland, S. A. (2019). The role of regulatory focus and trustworthiness in knowledge transfer and leakage in alliances. Industrial Marketing Management, 83, 162-173. doi:10.1016/j.indmarman.2019.03.014

44. Raza, S. H., Iftikhar, M., Mohamad, B., Pembecioglu, N., \& Altaf, M. (2020). Precautionary Behavior Toward Dengue Virus Through Public Service Advertisement: Mediation of the Individual's Attention, Information Surveillance, and Elaboration. Sage Open, 10(2), 15. doi:10.1177/2158244020929301

45. Roucolle, C., Seregina, T., \& Urdanoz, M. (2020). Measuring the development of airline networks: Comprehensive indicators. Transportation Research Part a-Policy and Practice, 133, 303-324. doi:10.1016/j.tra.2019.12.010

46. Schouten, A. P., Janssen, L., \& Verspaget, M. (2020). Celebrity vs. Influencer endorsements in advertising: the role of identification, credibility, and Product-Endorser fit. International Journal of Advertising, 39(2), 258-281. doi:10.1080/02650487.2019.1634898 


\section{JOURNAL OF TOURISM AND SERVICES}

Issue 23, volume 12, ISSN 1804-5650 (Online)

www.jots.cz

47. Seetanah, B., Sannassee, R. V., Teeroovengadum, V., \& Nunkoo, R. (2019). Air access liberalization, marketing promotion and tourism development. International Journal of Tourism Research, 21(1), 76-86. doi:10.1002/jtr.2242

48. Seo, Y., Li, X., Choi, Y. K., \& Yoon, S. (2018). Narrative Transportation and Paratextual Features of Social Media in Viral Advertising. Journal of Advertising, 47(1), 83-95. doi:10.1080/00913367.2017.1405752

49. Sevilla, J., Lu, J., \& Kahn, B. E. (2019). Variety Seeking, Satiation, and Maximizing Enjoyment Over Time. Journal of Consumer Psychology, 29(1), 89-103. doi:10.1002/jcpy.1068

50. So, K. K. F., King, C., Hudson, S., \& Meng, F. (2017). The missing link in building customer brand identification: The role of brand attractiveness. Tourism Management, 59, 640-651. doi:10.1016/j.tourman.2016.09.013

51. Suk, M., Kim, M., \& Kim, W. (2020). The moderating role of subjective norms and selfcongruence in customer purchase intentions in the LCC market: Do not tell me I am cheap. Research in Transportation Business \& 100595. doi:https://doi.org/10.1016/j.rtbm.2020.100595

52. Tang, N. Y. A., Wu, C. L., \& Tan, D. (2020). Evaluating the implementation of performancebased fuel uplift regulation for airline operation. Transportation Research Part a-Policy and Practice, 133, 47-61. doi:10.1016/j.tra.2019.12.028

53. Tang, Q., Liu, F., Liu, S., \& Ma, Y. F. (2019). Consumers' redemption behavior of recommended mobile coupons in social network sites. Management Decision, 57(9), 2477-2500. doi:10.1108/md03-2017-0234

54. Tran, G. A., Yazdanparas, A., \& Strutton, D. (2019). Investigating the marketing impact of consumers' connectedness to celebrity endorsers. Psychology \& Marketing, 36(10), 923-935. doi:10.1002/mar.21245

55. Trivedi, J. P. (2018a). Measuring the Comparative Efficacy of Endorsements by Celebrities Visa-vis Animated Mascots. Journal of Creative Communications, 13(2), 117-132. doi:10.1177/0973258618761407

56. Trivedi, J. P. (2018b). Measuring the comparative efficacy of an attractive celebrity influencer visà-vis an expert influencer - a fashion industry perspective. International Journal of Electronic Customer Relationship Management, 11(3), 256-271. https://doi.org/10.1504/IJECRM.2018.093771

57. van Pinxteren, M. M. E., Wetzels, R. W. H., Ruger, J., Pluymaekers, M., \& Wetzels, M. (2019). Trust in humanoid robots: implications for services marketing. Journal of Services Marketing, 33(4), 507-518. doi:10.1108/jsm-01-2018-0045

58. Vatankhah, S., Zarra-Nezhad, M., \& Amirnejad, G. (2019). An empirical assessment of willingness to accept "low-cost" air transport services: Evidence from the Middle East. Journal of Tourism and Services, 10(18), 79-103. doi:10.29036/jots.v10i18.92

59. Vatankhah, S., Zarra-Nezhad, M., \& Amirnejad, G. (2019). An empirical assessment of willingness to accept "low-cost" air transport services: Evidence from the Middle East. Journal of Tourism and Services, 10(18), 79-103. doi:10.29036/jots.v10i18.92

60. Vinzenz, F. (2019). The added value of rating pictograms for sustainable hotels in classified ads. Tourism Management Perspectives, 29, 56-65. doi:10.1016/j.tmp.2018.10.006

61. Wang, S. W., \& Scheinbaum, A. C. (2018). Enhancing Brand Credibility Via Celebrity Endorsement Trustworthiness Trumps Attractiveness and Expertise. Journal of Advertising Research, 58(1), 16-32. doi:10.2501/jar-2017-042

62. Weinberger, M. G., \& Gulas, C. S. (2019). The emergence of a half-century of research on humour in advertising: what have we learned? What do we still need to learn? International Journal of Advertising, 38(7), 911-956. doi:10.1080/02650487.2019.1598831

63. Wen, X. J., \& White, P. Cultural settings and recommendations for small towns and villages to visit in China. International Journal of Tourism Research, 11. doi:10.1002/jtr.2417 


\section{JOURNAL OF TOURISM AND SERVICES}

Issue 23, volume 12, ISSN 1804-5650 (Online)

www.jots.cz

64. Xu, X. Y., Scott, N., \& Gao, J. (2017). Cultural influences on viewing tourism advertising: An eye-tracking study comparing Chinese and Australian tourists. Journal of Tourism and Services, 8(14), 30-46. Retrieved from < Go to ISI >://WOS:000419329400004

65. Yu, C. P., Zhang, Z. G., Lin, C. P., \& Wu, Y. J. (2020). Can data-driven precision marketing promote user ad clicks? Evidence from advertising in WeChat moments. Industrial Marketing Management, 90, 481-492. doi:10.1016/j.indmarman.2019.05.001

66. Yu, S. B., \& Hu, Y. J. (2020). When luxury brands meet China: The effect of localized celebrity endorsements in social media marketing. Journal of Retailing and Consumer Services, 54, 12. doi:10.1016/j.jretconser.2019.102010

67. Zakari, M., Dogbe, C. S. K., \& Asante, C. (2019). Effect of celebrity endorsement on telecommunication companies' reputation The moderating role of celebrity characteristics. Management Research Review, 42(12), 1297-1314. doi:10.1108/mrr-12-2018-0470

68. Zhu, Y. Q., Amelina, D., \& Yen, D. C. (2020). Celebrity Endorsement and Impulsive Buying Intentions in Social Commerce - The Case of Instagram in Indonesia: Celebrity Endorsement. Journal of Electronic Commerce in Organizations, 18(1), 1-17. doi:10.4018/jeco.2020010101

\section{Brief description of Author/Authors:}

\section{Edward C. S. Ku Professor}

ORCID ID: https://orcid.org/0000-0002-4412-4908

Affiliation: Department of Travel Management, Faculty, National Kaohsiung University of Hospitality and Tourism, No.1, Songhe Rd., Xiaogang Dist., Kaohsiung City, 81271, Taiwan (R.O.C), https://www.nkuht.edu.tw/app/home.php.

Email: edwardku@mail.nkuht.edu.tw

Edward C.S $\mathrm{Ku}$ is a professor in the Department of Travel Management at National Kaohsiung University of Hospitality and Tourism. He received a Ph.D. degree from the Graduate School of Business Administration, National Central University (Taiwan). His research interests include tourism management, electronic commerce, supply chain management, knowledge management, and information systems applied in travel management. His papers have been published in The Service Industries Journal, Service Business, Journal of Air Transport Management, Journal of Hospitality and Tourism Research, International Journal of Tourism Research, Journal of Travel and Tourism Marketing, International Journal of Hospitality Management, Internet Research, Online Information Research, and others. 